\title{
WOMEN POLICING, CHRONIC SPINSTERHOOD AND DIVORCE - A STUDY OF IMO STATE POLICE COMMAND, OWERRI, IMO STATE NIGERIA
}

\author{
Nkwocha, Daniel Ibeawuchi \\ $\mathrm{PhD}$, Department of Sociology, \\ Imo State University, Owerri \\ Imo State, Nigeria
}

\begin{abstract}
This work focused on Women Policing, Chronic Spinsterhood and Divorce in the Nigeria Police Force HQ, Imo State Police Command, Nigeria. Police officers are often called people's babysitters and their roles are not only to crack down on crimes and show their masculine side, but to protect and take care of the citizens of the country in which they are. After Nigeria got her freedom from the Britain in 1960, the Nigerian Police School began to recruit female graduates from high schools and colleges. The objective of the study is to ascertain the effects of job demand of female officers on instability of their family. The hypothesis for this study states that there is a significant relationship between job demand of female officers in the work place and family instability. the work was anchored on the rational choice theory. The survey research design was adopted. The proportionate stratified random sampling technique and the purposive sampling technique were adopted. Data were presented using simple percentages and tables, while the hypothesis was tested using the chi-square statistical tool. The study found that female officers job demand in the work place has led to family instability among women police officers.
\end{abstract}

Keywords- Women Policing, Chronic Spinsterhood, Divorce, Police, Family Instability.

\section{INTRODUCTION}

Police officers are often called people's babysitters and their roles are not only to crack down on crimes and show their masculine side, but to protect and take care of the citizens of the country in which they are. After Nigeria got her freedom from the Britain in 1960, the Nigerian Police School began to recruit female graduates from high schools and colleges. With changes in Nigerian's society, female crimes increasing and the emergence of the sex industry and violence upon women and children, the police force is depending more and more on policewomen to handle these sensitive areas Marcus In reviewing the development of policewomen, we see after the introduction of them (police women) into the force that their main responsibility is in responding to the demands from society and dealing with female crimes or crimes on women and children mess. After opening up the police force in Nigeria to females and through the requirement of gender equality, the police force has had to recruit new members through fair examinations, but the fact that female students have generally performed better than male students on the police recruitment examination but less on physical examination has resulted in recruiting an excessive number of males to take on police strenuous duties. Also, the innate weakness of females compared to males often causes difficulties in assigning field duties by the police stations. Therefore, the purpose of this study is to explore if females are indeed suitable for police duties.

In recent times, the Nigeria Police Force are currently recruiting women to do some of the work that its male officers are doing without due consideration that their strength level may not be the same. These women are allowed to handle guns, stay on the roads, and are also allowed to run night shifts. These has to some extent affected the family life of these female officers, as some of them may no longer have enough time to carter for their various families. Also, this could also affect female officers who are single as single could be afraid of approaching them because of the nature of their jobs.

Therefore, this study tends to investigate whether female policing has led to divorce in the homes of female police officers in Nigeria, and whether the involvement of women in police has made them become spinsters for too long.

\section{OBJECTIVE OF THE STUDY}

To ascertain the effects of job demand of female officers on instability of their family

\section{HYPOTHESIS}

There is a significant relationship between job demand of female officers and family instability. 


\section{International Journal of Engineering Applied Sciences and Technology, 2019 Vol. 4, Issue 8, ISSN No. 2455-2143, Pages 9-13 \\ Published Online December 2019 in IJEAST (http://www.ijeast.com)}

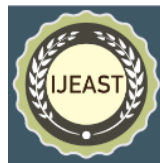

\section{LITERATURE REVIEW AND THEORETICAL FRAMEWORK}

Recruitment of Women in Law Enforcement Police administrators are facing a debilitating crisis; previous recruitment efforts have failed to sufficiently increase female officer representation. In the early 20th century, women were recruited to handle troubled teen girls after political pressure was 22 applied by women's groups (Appier, 1998). Today, female officers are still on a mission to redefine their roles as police officers. However, the literature related to the recruitment of female officers remains sparse, and locating adequate data remains a challenge. Consequently, it is difficult to monitor women's progress or the effectiveness of recruitment programs. For instance, Prenzler \& Sinclair (2013) conducted an international assessment related to the status of women in policing, comparing findings from police departments in 16 countries: England, Wales, Scotland, Northern Ireland, United States, Erie, New Zealand, South Africa, Ghana, Nigeria, Canada, Australia, India, Pakistan, Hong Kong, Papua New Guinea, and Fiji. In 2010, female officer representation in the United States was at $11.8 \%$ when examining data from 14,744 agencies (Prenzler \& Sinclair, 2013). Furthermore, India had the lowest female representation at 5.1\% in 2010 (Prenzler \& Sinclair, 2013). There is a need to conduct further research on the recruitment of female officers. The need for special legislation to improve equal employment opportunities for women in the labor force is apparent in most police research (Prenzler \& Sinclair, 2013; Rabe-Hemp, 2008). Such legislation led to Felicia Schpritzer, a New York policewoman, successfully suing the city in 1961 to take the sergeant's examination (Duffin, 2010; Koenig, 1978; Rabe-Hemp, 2008). Schpritzer's case was litigated through the Supreme Court of New York, and her efforts set a new precedent allowing female officers to apply to take promotion exams. Through her commitment to increase equality for women in policing, she helped paved the way for other women to freely seek advancement opportunities during their law enforcement careers. With her effort and the support o 23 federal government, women felt more compelled to fight for equal rights as policewomen. Women comply with or tolerate unfair departmental rules while attempting to fully assimilate into the police culture (NCWP, 2002; Prenzler \& Sinclair, 2013). Possible inequities become apparent to female officers during the recruitment phase, the police academy, and extend throughout the female officer's career. For example, agency administrators discouraged male officers from socializing with female officers in an effort to embellish any perceived differences (Shelley et al., 2011). Moreover, women are routinely assigned gender-specific duties, which involve women being pulled from the streets to deal with socialservice-related issues such as caring for runaway teens (Krimmel \& Gormley, 2003; Rabe-Hemp, 2011). However, confining female officers to caregiver duties is not always desirable to potential candidates and may be viewed as subtle discrimination (Rabe-Hemp, 2011). To combat this problem, women's organizations recommend that agencies develop recruitment programs that display women performing a variety of police duties. Each program should include an unbiased recruitment committee, female panelist, media campaigns, properly trained recruiters, and a strategy to monitor all recruitment efforts (Langston, 2010; NCWP, 2002). Some agencies have eliminated the traditional boot camp model in order to increase the effectiveness of recruitment campaigns. This includes adopting a form of policing known as community policing (Matthies, Keller, \& Lim, 2012). The community policing model was adopted during the late $1980 \mathrm{~s}$ and the 1900s. It is a style of policing that helps residents build rapport with police, create personal connections, as well as 24 increase the agency's legitimacy (Matthies et al., 2012; Miller, 1999). Many citizens tend to favor the elements of community policing that stress community education, victim assistance, public service, and collaborative policing (Prenzler \& Sinclair, 2013; Rabe-Hemp, 2008, 2011; Zhao et al., 2001). Community policing has been successful because it relies on the positive attributes of female officers, such as emphasizing communication to de-escalate hostile situations and rarely discharging duty weapons (Krimmel \& Gormley, 2003; Prenzler \& Sinclair, 2013; Rabe-Hemp, 2008, 2011). Additionally, female officers tend to favor community policing because women are known to be more patient and supportive of citizens (Lonsway, 2003). It is actually a more community friendly approach to policing; however, there appears to be a social service feature involved. There is a need for agencies to redefine the skills and representation of what it means to be a police officer (NCWP, 2010). Perhaps it would be helpful if agencies looked beyond traditional methods of recruiting, such as military personnel, because the population of women in that profession is also low (NCWP, 2010). While candidates with military experience are typically viewed as a better fit to the traditional police model, researchers argue that seeking candidates from other diverse professions may be beneficial. Women were used in the police force because of public concern about allegations of police brutality, corruption, as well as the high cost of litigating these cases (Duffin, 2010; Hassell et al., 2011; NCWP, 2002; Rabe-Hemp, 2008; Seklecki \& Paynich, 2007). However, the literature did not offer explanations for why some administrators are doing 25 a poor job of recruiting more females. In fact, most of those studies include respondents from correctional institutions and focus on female officer motivations for pursuing a police career and their work environment. This further revealed the importance of creating more dialogue related to female police officer's work experiences and the traditions they hope to generate (Rabe-Hemp, 2008; Shelley et al., 2011). In conclusion, there is a need for future research surveying participants from law enforcement agencies and not juvenile or correctional facilities. The research also revealed a need to eliminate the traditional police model and seek police candidates from sources other than the military (NCWP, 2010). Creating opportunities for female officers to earn leadership and supervisory positions has also been suggested. 


\section{International Journal of Engineering Applied Sciences and Technology, 2019 Vol. 4, Issue 8, ISSN No. 2455-2143, Pages 9-13 \\ Published Online December 2019 in IJEAST (http://www.ijeast.com)}

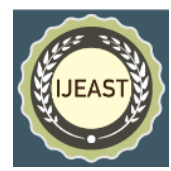

This is pertinent since the number of females continues to fluctuate and has yet to reach a representation of 20 percent. Overall, data related to female officer's roles, recruitment, and current status is conflicting. Some researchers report an increase in female officer representation, while others report a steady decline (Langston, 2010). Based on the research, it may be necessary to re-evaluate and adjust many of the skills previously required to successfully complete police academies. Historically, women's organizations have been critical of any disparities, which have resulted in an increase in recruitment programs, Civil Rights legislation and implementation of community policing models to decrease the hiring gap. As a result, additional research is necessary to effectively record women's presence and contributions to the law enforcement profession.

\section{Female officers job demand in the work place and family instability}

According to Ubong and Unyime (2015), women's employment undoubtedly appears to create pressure for changes in the internal dynamics and organizations of family life. Women have made adjustments such as employment of house helps and nannies to help in home obligation due to their involvement in paid labour. They do less of the tasks traditionally thought as "women's work". For them, this process may not be without problem for the family. Women spend long hours at different paid jobs and in most cases do not have the time for their children. They further states that change in women's occupation have significant influence on family obligation of women and subsequently affects the level of care for their children which could eventually lead to family instability.

Ajiroba (2018), reports that working mothers feel guilt about leaving their spouse and children for long due to paid work engagement. His study revealed that spouses feel angry and resentment at being left alone uncared for and to manage the household. They are of the opinion that absence of the wives at home entails an awkward readjustment period, and concludes that frequent absence can result in a gradual emotional distancing between spouses. In the view of

Basil (2015), it is common for women for husbands and wives not to stay together. That is why some women are referred to as "weekend mothers". In this case, the woman stays in her place of work during the week and joins the family at weekend depending on distance. Some women resides in other countries and may not see their children for years, which may have negative effects on the family. For him, this was not so in the past as women are supposed to be main care- providers in the family and they are supposed to be very close to their husbands and children in order to avoid instability in the family.

Maduba (2016) contends that in the process of looking for money to carter for other family needs, women tend to forget that their main role as mothers is to constantly monitor their children's development and way of life and also care for their husbands. He further stated that women that only provide money for family needs without proper care for their family members, may face the problem of trying to keep her family together in the latter days of her life. For him, the major problem in trying to measure the effect of women's employment pattern on longer- term outcomes for their family is that women choose their occupational pattern in conjunction with choices about the way they spend their time and money on their family. This emphasizes the need to take account of other factors like children's educational achievements which is one of the primary duties of a mother in the home.

Chibuzor (2016) argues that motherhood confers upon a woman the responsibility of raising a child. This process also changes the way in which she is perceived in society and at her work place. It can necessitate her to take more available leave options, and job security can be at risk. Significant social and personal adjustments are necessary to cope with such situations. He further states that a working mother especially one who has the good fortune to be available to balance her home and work, enjoys the stimulation that a job or career provides. She develops the ability of raising useful members of society, and at the same time, gains financial independence.

Femi and Olu (2015) contend that when a woman's occupation changes, time to care for her husband becomes an issue. According to them, time issue is a critical aspect of paid work and family life. Wives needs enough time at home to take care of their husband, and at work place they also need to put enough hours so as to achieve the objectives of the organization. In the Nigerian society, it is almost a taboo for a man to help his wife with house chores. He would be ridiculed by friends who would call him names like "woman wrapper" behind his back or even to his face. The average Nigerian man believes that the house chores which include care for their husbands and child care obligation.

Aguoru (2015) thereby states that significant relationship exists between women's job demand in the work place and care for husband. For him, women who cannot care for their husbands at home will also find it difficult to handle office activities.

The rational choice theory was popularized by George Homans (1961). The rational choice theory is a framework for understanding social and economic behaviour. The basic premise of this theory is that aggregate social behavoiur results from behaviour of individual actors, each of whom is making their individual decisions. The theory also focuses on the determinants of individual choices. Rational choice theory then assumes that an individual has preferences among available choice alternatives that allow them to state which option they prefer.

Women, since their entry into the labour market, have it difficult to make a clear choice between their work and family obligations. Women who choose their work ahead of family obligations/ child care obligations may suffer instability in their various families. The choice a woman 


\section{International Journal of Engineering Applied Sciences and Technology, 2019 \\ Vol. 4, Issue 8, ISSN No. 2455-2143, Pages 9-13 \\ Published Online December 2019 in IJEAST (http://www.ijeast.com)}

makes will make her lose either her paid work or her family, the inability of the woman to effectively make a choice that will help her balance her home duties with her office duties could lead to instability in the family which could cause divorce.

\section{METHODOLOGY}

The research design for this study is survey research design. Survey research design means the investigation of the behavior, opinion or other manifestations of a group of people by questioning them. The researcher adopted the survey research design because of its flexibility to permit the use of variety of data collection techniques. Also, survey research design sensitizes the researchers to potential problems that were originally unknown.

The population of personnel in Imo State Police Command is 410, while the researcher purposively chose 145 respondents as the sample size of this study.

Table 1 Departments and their Sample size Proportion

\begin{tabular}{|l|l|l|}
\hline Items & Departments & No of personnel \\
\hline 1 & CID & 40 \\
\hline 2 & SIB & 33 \\
\hline 3 & F-SARS & 40 \\
\hline 4 & ANTI KIDNAPPING & 44 \\
\hline 5 & ANTI CULTISM & 51 \\
\hline 6 & MONITORING UNIT & 41 \\
\hline 7 & CP SURVEILANCE & 46 \\
\hline 8 & ANTI VICE & 42 \\
\hline 9 & SAFER HIGH WAY & 42 \\
\hline 10 & THE ARMBUSH SQUARD & 31 \\
\hline TOTAL & & 410 \\
\hline
\end{tabular}

Source: (Administrative and Human Resources department of the Nigeria Police Force, Imo State Command).

The researcher adopted proportionate stratified sampling technique and purposive sampling technique. Data were collected using questionnaire. Data were presented using simple percentages and tables, while the research hypothesis was tested using the chi-square $\left(\mathrm{X}^{2}\right)$ statistical tool. This is because it gives the opportunity to establish relationship between variables.

\section{RESULT AND DISCUSSION}

Table II: Distribution of Questionnaire

\begin{tabular}{|l|l|l|l|l|l|}
\hline S/N & Departments & $\begin{array}{l}\text { Questio } \\
\text { nnaire } \\
\text { distribu } \\
\text { ted }\end{array}$ & $\begin{array}{l}\text { Quest } \\
\text { ionna } \\
\text { ire } \\
\text { retur } \\
\text { ned }\end{array}$ & $\%$ \\
\hline 1 & CIB & 30 & 20 & 30 & 20.6 \\
\hline 2 & F-SARS & 30 & 20 & 30 & 20.6 \\
\hline 3 & $\begin{array}{l}\text { Anti- } \\
\text { Kidnapping }\end{array}$ & 30 & 20 & 26 & 17.9 \\
\hline 4 & $\begin{array}{l}\text { Monitoring } \\
\text { Unit }\end{array}$ & 30 & 20 & 30 & 20.6 \\
\hline 5 & $\begin{array}{l}\text { CP } \\
\text { Surveillance }\end{array}$ & 30 & 20 & 29 & 20 \\
\hline & Total & 150 & 100 & 145 & 100 \\
\hline
\end{tabular}

$\%$ frequency distributed $=\underline{\text { No. of questionnaire distributed } \times 100}$ Total questionnaire distributed

$\%$ frequency returned $=\underline{\text { No of questionnaire returned } \times 100}$ Total questionnaire returned

$1,2,3,4$ and 5 respectively.

Table III Chi-Square Analysis for Female officers job demand in the work place and family instability

\begin{tabular}{|l|l|l|l|l|l|}
\hline Items & SA & A & D & SD & Total \\
\hline 2 & 120 & 5 & 10 & 10 & $145 \mathrm{~B} 1$ \\
\hline 5 & 10 & 5 & 10 & 120 & $145 \mathrm{~B} 2$ \\
\hline Total & $130 \mathrm{~A} 1$ & $10 \mathrm{~A} 2$ & $20 \mathrm{~A} 3$ & $130 \mathrm{~A} 4$ & 290 \\
\hline
\end{tabular}

Placing the observed and expected values in a tabular form, we have;

Table IV: Data for hypothesis one

\begin{tabular}{|l|l|l|l|l|}
\hline $\mathrm{O}$ & & $\mathrm{E}$ & $(\mathrm{O}-$ & $(\mathrm{O}$ \\
$\mathrm{E})$ & $\mathrm{E})^{2 / \mathrm{E}}$ \\
\hline 130 & & 65 & 65 & 2 \\
\hline 10 & & 72.5 & 62 & 1.7 \\
\hline
\end{tabular}




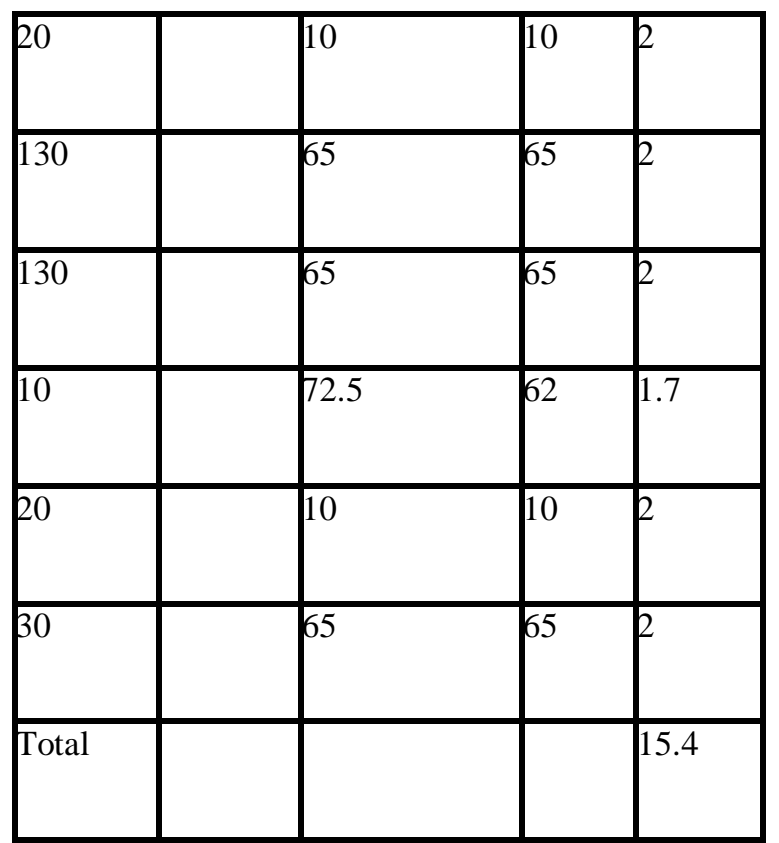

The table above is a $4 \times 2$ contingency table, hence the degree of freedom.

$(\mathrm{df})=(\mathrm{C}-1)(\mathrm{R}-1)$

$(\mathrm{df})=(4-1)(2-1)$

df $=3 \times 1=3$

Thus, df $=3$.

The table value of $x^{2}$ at a significance level of 0.05 and degree of $3=7.815$. The calculated value of $x^{2}=15.4$. Since the calculated value of $x^{2}$ is greater than the table value of $\mathrm{x}^{2}$, we thereby accept the alternate hypothesis which states that: There is a significant relationship between female officers job demand in the work and family instability.

\section{Discussion of findings}

From the analysis of the study on female police officers, chronic spinsterhood and divorce we found that:

Female officers job demand in the work place has caused some of them (female police officers) their homes. This is in line with Ugwulebo (2011) that women travel a lot in search of economic fortunes and during their trips, the home suffers abandonment.

\section{CONCLUSION}

Based on the research findings, we conclude that;

Women officers are still trying to balance between their needs at home and their office duties. Despite the fact that female police officers spend the money they get on their family especially their children, they still face some subtle instability in their various homes. Also, female police officers become chronic spinsters not because of the nature of their jobs, but because of the way they carry themselves.

\section{Recommendation}

The study recommends that women police officers should not be posted to areas that will make them not see their family members for a long time.

\section{REFERENCE}

[1] Ajiroba O.(2018). Women Employment in the Third World Countries. Journal of Gender and International Studies. 9(1) (pp. 86-90).

[2] Aquoru G. (2015) Education and Changing Careers of Women in Nigeria. Onitsha: Maduabuchi Printing Press.(pp. 62-68).

[3] Basil C. (2015). Women's Work and Family Flexibility. Benin: Gifted Hands Publishers. (86-89).

[4] Duffin M. (2010). Women and Crime in Africa. Dublin: Lewin Publishers. (pp. 92-98).

[5] Krimmel J.T and Gormley P.E. (2003). Tokenism and Job Satisfaction for Policewomen and their Fight for Acceptance. American Journal of Criminal Justice. 28(1) (pp73-88).

[6] Langston L. (2010). Gender and Invovement in ParaMilitary Recruitment. Yenagoa: Living Stream Publishers. (pp. 62-88).

[7] Maduba C. (2016). Women in the Informal Sector and Divorce. Journal of Human Resources Management. 16(12). (pp. 22-26).

[8] Mathies C F., Keller M., and Lim N. (2012). Identifying Barriers to Diversity in Law Enforcement Agencies. Santa Monica: Rand Corporation. (pp. 370-378).

[9] Prenzler T and Sinclair G. (2013). The Status of Women Police Officers: An International Review. International Journal of Law, Crime and Justice. (pp. 115-131).

[10] Rabe-Hemp C. (2008). Survival in an "All Boys Club": Policewomen and their Fight for Acceptance. International of Police Strategies and Management. 3(2) (pp. 251-270).

[11] Shelley C. (2011). The Impact of Women in the Industrial Sector.London: Rodney Publishers. (pp. 61-68).

[12] Ubong C. and Unyime M. (2015) Women Officers Job Demand and Family Stability. Journal of Sociology and Anthropology. 6(4). (pp. 22-36).

\section{ACKNOWLEDGEMENTS}

We acknowledge all the authors that their works were cited in this research. 